\title{
Perspektif Orang Tua Tentang Perilaku Bullying Anak TK: ditinjau dari Tingkat Pendidikan
}

\author{
Fransiskus Ghunu Bili1 ${ }^{凶}$, Sugito ${ }^{2}$ \\ Pendidikan Anak Usia Dini, Universitas Negeri Yogyakarta \\ DOI: $10.31004 /$ obsesi.v5i2.939
}

\begin{abstract}
Abstrak
Penelitian ini bertujuan untuk menyelidiki perspektif orang tua terhadap perilaku bullying anak TK ditinjau dari tingkat pendidikan berkaitan dengan pemahaman: tentang konsep bullying, bahaya perilaku bullying bagi anak TK, keterlibatan orang tua dalam mengintervensi awal perilaku bullying anak, peran tingkat pendidikan orang tua dalam menanggapi perilaku bullying pada anak. Penelitian ini menggunakan pendekatan kualitatif deskriptif untuk mengeksplorasi pandangan dari 6 orang tua anak, dengan usia anak 5-6 tahun yang bersekolah di TK Tunas Harapan Weetebula. Melalui wawancara terhadap pemahaman tentang perilaku bullying anak dan meninjau literatur yang menyoroti perspektif orang tua dengan tingkat pendidikan terakhir mereka. Berdasarkan hasi studi ini menunjukkan bahwa perspektif orang tua dengan tingkat pendidikan yang berbeda sangat berperan penting dalam mensikapi tentang perilaku bullying anak ditaman kanak-kanak.
\end{abstract}

Kata kunci: perspektif orang tua; perilaku bullying anak; tingkat pendidikan

\begin{abstract}
This study aims to investigate parents 'perspectives on bullying behavior in kindergarten children in terms of educational level related to understanding: the concept of bullying, the dangers of bullying behavior for kindergarten children, the involvement of parents in intervening early children's bullying behavior, the role of parents' educational level in responding to behavior bullying in children. This study used a descriptive qualitative approach to explore the views of 6 parents of children, aged 5-6 years who attend TK Tunas Harapan Weetebula. Through interviews with understanding of children's bullying behavior and reviewing literature that highlights the perspectives of parents with their latest educational level. Based on the results of this study, it shows that the perspectives of parents with different levels of education play an important role in responding to the bullying behavior of children in childhood.
\end{abstract}

Keywords: parents' perspective; children's bullying behavior; education level

Copyright (c) 2020 Fransiskus Ghunu Bili, Sugito

$\triangle$ Corresponding author:

Email Address : weningsekar13@gmail.com (Yogyakarta, Indonesia)

Received 1 December 2020, Accepted 22 December 2020, Published 30 December 2020 


\section{PENDAHULUAN}

Perilaku bullying yang terjadi pada anak usia prasekolah atau Tk, sering disalah artikan oleh orang tua sebagai kenakalan anak karena ketidak pahaman anak terhadap tindakannya tersebut termasuk dalam golongan bullying dan orang tua beranggapan bahwa anak belum mengerti perbuatan tersebut. Sehingga perspektif atau sudut pandang awal yang muncul dari orang tua adalah semata kenakalan biasa disebabkan anak masi dalam rentang usia dini. Hal ini sejalan dengan pendapat (Dey Putri et al., 2020) mengatakan bahwa perilaku bullying anak prasekolah sering diabaikan atau disalah pahami oleh orang tua dengan anggapan anak belum memahami yang benar dan yang buruk.

Faktor ini terjadi menurut penelitian (Dey Putri et al., 2020) dipengaruhi oleh rendah keterlibatan orang tua dan regulasi dirinya dan adanya gagasan penolakan guru bahwa anak terlibat sebagai pelaku intimidasai maupun korban intimidasi di sekolah membuat orang tua kurang melihat secara detail bahwa anak-anak mereka telah mengambil bagian sebagai pelaku atau sudah menjadi korban bullying atau perundungan (Hein, 2017). Selain itu, hal yang sering ditemukan bahwa pandangan awal orang tua ketika ditanyakan tentang perilaku bullying paling umum mengenal sebagai perkelahian (Sharp \& Smith, 2019). Apabila dilihat dengan benar perkelahian dapat dipahami sebagai konflik yang memiliki kekuatan yang setara. Pendapat di atas disimpulkan bahwa orang tua masi belum memiliki perspektif yang kaya tentang perilaku bullying anak mereka dalam masa usia prasekolah atau taman kanak-kanak (TK) dan juga dipengaruhi oleh keterlibatan yang rendah dari orang tua untuk mengenal perilaku bullying anak mereka.

Perilaku bullying sendiri didefenisikan sebagai tindakan fisik secara langsung maupun dengan ungkapan verbal yang berupa memukul, mencubit, mendorong, memeras, merusak barang-barang milik orang lain, mengucapkan kata cemooh, mengejek dengan nama yang tidak sopan (Santoso, 2018). Sedangkan menurut, Olweus (1973), sebagai mana dikutip oleh (Saracho, 2017) mengatakan bullying merupakan intimidasi yang terjadi dimana seseorang mendapatkan perilaku yang terjadi berulang-ulang kali dan berkelanjutan dalam kurun waktu yang lama, berupa tindakan negatif sekelompok siswa maupun perorangan. Olweus juga membagi perilaku bullying dalam tiga ketegori yaitu, (a) perilaku agresif, (b) perilaku yang terjadi berulang-ulang seiring waktu, (c) adanya hubungan interpersonal yang ditandai dengan terjadinya ketidak seimbangan kekuasan (Maria \& Novianti, 2017). Maka dengan pemahaman akan defenisi perundungan dengan baik diharapkan orang tua menyadari dan mampu mengkategorikan bahwa perilaku bullying yang terjadi pada anak di taman kanakkanak tidak terbatas pada kenakalan biasa namum merupakan tindakan intimidasi yang dapat berpengaruh secara fisik dan psikologi untuk perkembangan anak.

Penelitian oleh (Harcourt et al., 2014) dengan melakukan wawancara semiterstruktur terhadap orang tua yang anaknya bersekolah pada taman kanak-kanak dengan usia 4-5 tahun menemukan bahwa orang tua perlu memahami tentang penindasan atau intimidasi dengan bertanggung jawab mencari informasi dukungan mengenai hal-hal tentang bullying. Sehingga perspektif dari orang tua terhadap perilaku bullying anak tidak hanya terbatas pada kenakalan biasa yang dilakukan oleh anak namum lebih memahami sebagai suatu tindakan yang memiliki efek jangka panjang untuk perkembangan anak dalam rentang usia pertumbuhannya. Orang tua juga diharapkan perlu mengedukasi diri dengan mencari berbagai sumber informasi merupakan cara yang efektif untuk mengenal bullying lebih dalam.

Penelitian oleh (Robbiyah et al., 2018) tentang pola asuh ibu dan meilihat pengaruhnya pada kecerdasan sosial anak menunjukkan bahwa anak mengalami peningkatan kecerdasan sosial dan emosional secara positif dengan memperlihatkan perilaku disiplin, memiliki motivasi bersekolah, minat terhadap aktivitas belajar dan menunjukkan hubungan interaksi sosial dengan teman-teman sebaya. Dari jabaran hasil penelitian diatas menggambar bahwa pola asu ibu terhadap anak sangat berpengaruh terhadap perkembangan sosial dan emosional anak dimana dapat menekan setiap potensi perilaku anak agar tidak berkembang menuju 
pada perilaku perundungan (bullying), namun memperlihatkan perilaku sosial terhadap penerimaan teman sebayannya sebagai anggota suatu kelompok.

Penelitian (Maria \& Novianti, 2017), menemukan peran pola asuh dan bullying berpengaruh terhadap meningkatnya kepercayaan diri anak usia 5-6 tahun dalam menghadapi bullying. Dimana pengaruh positif pola asuh membantu anak dalam mengenal konsep diri. Sehingga jenis pola asuh yang diterapkan oleh orang tua terhadap anak dengan pemenuhan kebutuhan fisik dan psikologi berpengaruh terhadap perkembangan karakter anak yang nanti anak dapat tumbuh dan berkembang sesuai dengan norma-norma yang berlaku dilingkungannya (Ditha \& Dinda, 2018). Penerapan pola asu yang tepat oleh orang tua dengan pemahaman akan konsep dari jenis pola asu yang ada sperti, demokratis, otoriter, permitif sangat berpengaruh terhadap perkembangan karakter anak. Sedangkan karakter anak berkaitan dengan sikap yang ditampilkan anak termasuk bahwa orang tua mendidik anak agar tidak menampilkan karakter yang salah dengan berperilaku bullying terhadap teman sebaya mereka.

Pendidikan orang tua juga berpengaruh terhadap pandangan mereka tentang perilaku perundungan anak mereka dalam rentang usia prasekolah atau masuk dalam kategori anak usia dini. Dimana, orang tua yang berpendidikan tinggi akan memiliki perspektif pemahaman yang baik tentang bullying yang terjadi pada anak prasekolah dan akhirnya mereka mau melibatkan diri untuk memberikan intervensi awal dalam mencega perilaku tersebut.

Orang tua yang berpendidikan tinggi tentunya memiliki akses lebih luas untuk mempelajari atau mencari tahu tentang perilaku bullying anak dan efeknya untuk perkembangan anak dan karenanya orang tua sendiri dikatakan sebagai peletak dasar segalah pengatahuan atau modelling bagi anak dalam mengatasi perilaku bullying (Dey Putri et al., 2020). Keterlibatan orang tua sekaligus menggambarkan bahwa orang tua memiliki pemahaman dan pandangan yang luas tentang perilaku bullying anak di usia prasekolah atau taman kanak-kanak karena faktor tingkat pendidikan yang dimiliki. Sudut pandang dalam dan lebih luas tentang perilaku bullying membantu orang tua dalam mempelajari dan memahami setiap sikap maupun tindakan anak apakah termasuk dalam kategori perilaku perundungan atau tidak. Selain itu, orang tua dapat menjadi faktor resiko dan perlindungan bagi anak. Apabila ayah atau ibu memberikan hukuman fisik dan tidak memberikan kehangatan atau kebahagian bagi anak maka anak juga berpotensi untuk melakukan tindakan kekerasan fisik bagi anak lain yang dikategorikan sebagai bullying sebab hal tersebut berangkat dari rendahnya pendidikan yang dimiliki orang tua dan kurangnya pengetahuan tentang perilaku bullying (Herne, 2016).

Bullying atau perundungan bukanlah kasus baru yang terjadi di sekolah- sekolah di Indonesia bahkan terjadi di taman kanak-kanak (TK). United National Internasional Children's Emergency Fund (UNICEF) mengeluarkan penilain dengan menempatkan Indonesia pada peringkat yang tinggi terjadi kekerasan atau bullying pada anak dimana perspektif masyarakat menganggap hal tersebut biasa (Elmahera, 2018). Dari pendapat di atas menempatkan kurangnya kepekaan masyarakat terhadap perilaku bullying yang terjadi pada anak di sekolah maupun dikeluarga sehingga proses intervensi awal terlambat dan mengakibatkan banyak kasus yang terjadi. Orang tua adalah bagian dari masyarakat perspektif atau sudut pandang awal yang kritis dari mereka yang mendalam memahami bullying dapat memberikan pengetahuan untuk melakukan pencegahan maupun menekan perilaku itu terjadi sedini mungkin pada anak.

Penelitian-penelitian sebelum melihat peran pola asuh dan peran orang tua menemukan informasi tentang bullying sebagai faktor utama pendukung dalam mengatasi perilaku bullying anak-anak pada usia prasekolah. Sedangkan penelitian yang dilakukan oleh peneliti lebih menfokuskan penekankan pada perspektif atau pandangan orang tua tentang perilaku bullying anak Tk dengan memilih orang tua yang memiliki tingkat pendidikan akhir 
Perspektif Orang Tua Tentang Perilaku Bullying Anak TK: ditinjau dari Tingkat Pendidikan

DOI: 10.31004/obsesi.v5i2.939

yang berbeda dan bagaimana sikap mereka dalam memaknai atau memahami perilaku bullying anak.

\section{METODOLOGI}

Penelitian ini menggunakan pendekatan kualitatif deskriptif. Penelitian kualitatif dipahami sebagai penelitian dengan pendekatan non-numerik yang diartikan bahwa data yang diperoleh dapat berupa kata, gambar, perilaku, dan bersifat kontekstual dan pribadi (Christensen, et al., 2015). Metode kualitatif deskriptif digunakan untuk mengeksplorasi pandangan dari 6 orang tua anak, dengan usia anak 5-6 tahun yang bersekolah di TK Tunas Harapan Weetebula. Adapun subyek penelitian adalah orang tua dari anak yang memiliki tingkat pendidikan akhir atau bersekolah hanya sampai pada tingkat SD 2 orang: PMK dan VT , SMP 2 orang: YGO dan YWL, SMA 1 orang: MNW, dan Sarjana 1 orang: DS.

Pemilihan responden atau informan mengunakan purposive sampling dimana berdasarkan tujuan penelitian dan responden orang tua yang dipilih salah satu baik ayah maupun ibu sebagai perwakilan. Sedangkan teknik analisis data yang digunakan dalam penelitian ini dengan langkah-langkah pengumpulan data melalui studi literatur dan wawancara kemudian mereduksi data, penyajian data, pembahasan, dan penarikan kesimpulan. Adapun desain penelitian pada gambar 1.:

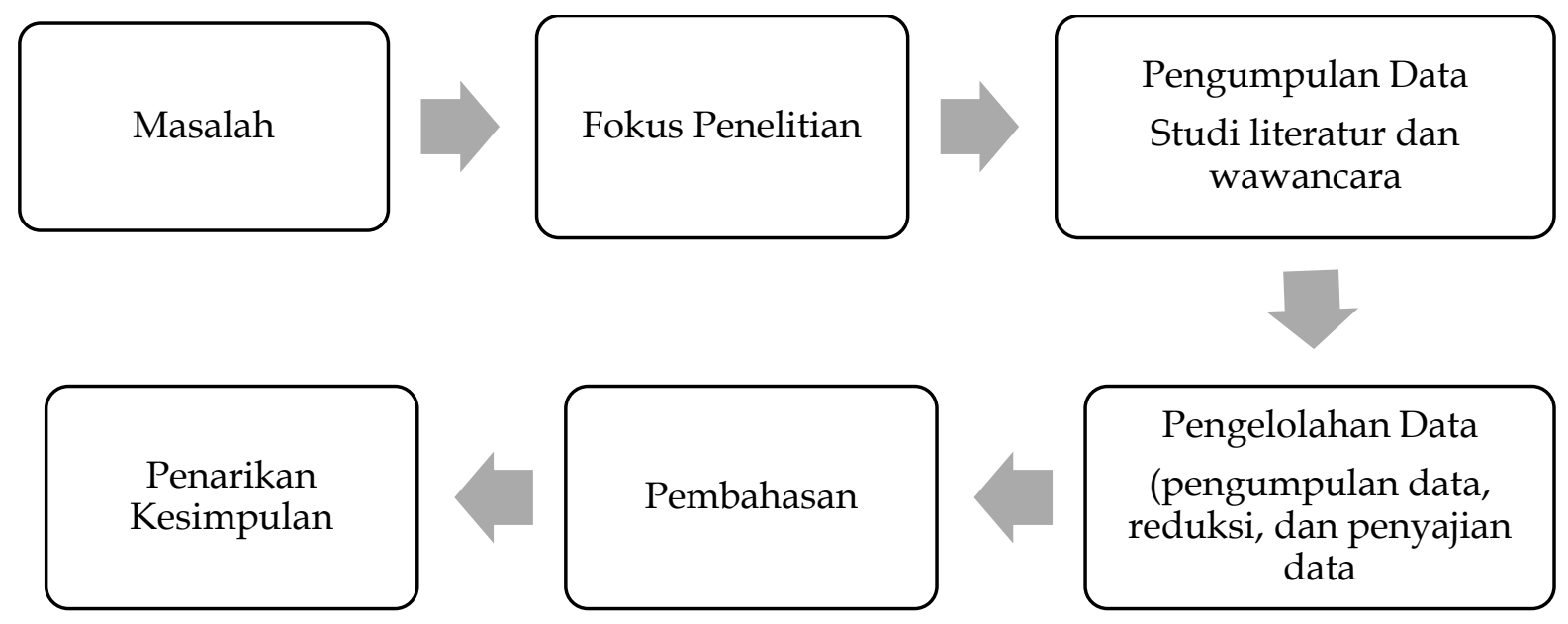

Gambar 1. Desain Penelitian

\section{HASIL DAN PEMBAHASAN}

\section{Konsep Bullying}

Memahami lebih dalam tentang konsep bullying sangat perlu bagi orang tua agar dapat menggenal dan melakukan pencegahan lebih awal perilaku ini terjadi pada anak usia TK dimana perilaku tersebut juga harus dipahami bahwa memiliki efek negatif dalam waktu yang cukup lama untuk perkembangan anak.

Berdasarkan hasil wawancara dengan orang tua mengenai perspektif mereka tentang konsep bullying dengan indikator bagaimana anda memahami konsep perilaku bullying atau perundungan?. Hasil wawancara tersebut dirangkum dalam tabel 1.

Dari hasil wawancara orang tua pada tabel 1 dapat ditarik kesimpulan bahwa pemahaman mereka terhadap konsep perilaku perundungan berkaitan erat dengan tingkat pendidikan terakhir. Menurut (Cross \& Barnes, 2014) menemukan bahwa tingkat pendidikan orang tua yang rendah berpeluang menjadikan pemahaman terhadap sikap bullying pada anak mereka rendah pula dan berakibat perilaku tersebut berkembang dalam diri anak. Artinya, orang tua memahami konsep bullying tidak sebatas kenakalan anak, anak menggangu teman, dan tidak ingin berteman namun pemahaman tentang konsep bullying lebih kearah tindakan yang merugikan secara psikis dan psikologi anak dan terjadi berulang- 
ulang. Selain itu, orang tua dengan jenjang pendidikan sarjana memberikan pandangan tentang konsep bullying dengan cukup baik karena memiliki akses untuk tahu tentang perilaku perundungan. Berbeda dengan orang tua yang hanya menyelesaikan pendidikan sampai pada jenjang sekolah dasar dan sekolah menengah pertama memahami konsep perundungan sebatas kenakalan atau perilaku menggangu anak dikarenakan akses mereka tentang konsep bullying yang terbatas maupun informasi berkaitan dengan bullying yang juga terbatas

\section{Tabel 1. Perspektif orang tua tentang konsep bullying}

\begin{tabular}{ll}
\hline \multicolumn{1}{c}{ Lulusan } & \multicolumn{1}{c}{ Perspektif orang tua } \\
\hline Sekolah & Kami sering mengenal secara umum merupakan perilaku kenakalan anak, atau anak \\
Dasar & kami pernah menceritakan bahwa membuat anak lain menangis kerena berebutan \\
(SD) & mainan seperti mainan balok dan buku bergambar menurut kami hal tersebut \\
& mungkin karena kenakalan anak kami atau karena usia anak masih kecil dan hal \\
& demikian bisa terjadi pada usianya.
\end{tabular}

Sekolah Bullying menurut kami perilaku seperti anak memukul, mengganggu temannya atau Menengah tidak ingin berteman dengan anak lain dan kami pernah mendengarkan dari guru Pertama maupun anak kami sendiri bahwa teman mereka diperlakukan seperti itu. Kami (SMP) mendengar dari teman bahwa bully tidak baik, dimana perilaku tersebut sering dilakukan oleh anak yg kuat dan mengancam.

Sekolah saya mengenal bullying sebagai kategori tindakan agresif anak dan tindakan fisik Menengah dengan melakukan pukulan, mencubit, dan usil terhadap teman dengan mengambil Atas (SMA) mainan temannya.

Sarjana Saya sering mendengar kata bully dan saya memahami bahwa perilaku tersebut tidak baik untuk dilakukan oleh anak. Apa lagi anak TK akan sangat mengganggu perkembangan mereka. Bully menurut saya perilaku seperti, memukul, membuat anak tidak nyaman, menghambat perkembangan, mengganggu secara psikologi, dan perundungan membuat anak tidak ingin kesekolah.

Pemahaman yang luas tentang konsep bullying menurut (Rigby, 2019), mengatakan bullying atau perundungan merupakan masalah yang serius untuk ditindaki yang terjadi di sekolah karena efek negatif tersebut berlangsung dalam jangka pendak maupun dalam waktu yang lama bagi kesejahteraan dan Kesehatan anak. Sedangkan konsep bullying menurut, (Saracho, 2017) mengatakan bullying merupakan intimidasi yang terjadi dimana seseorang mendapatkan perilaku yang terjadi berulang-ulang kali dan berkelanjutan dalam kurun waktu yang lama, berupa tindakan negatif sekelompok siswa maupun perorangan..

Biasanya anak sebagai pelaku bullying memiliki hubungan yang dibangun atas dasar kekuasaan karena memiliki kekuatan untuk menekan dan mengendalikan orang lain agar mendapat milik mereka. Konsep bullying oleh (Sharp \& Smith 2019; Akerman, et al 2018) mengatakan bahwa tindakan agresor atau perilaku kasar yang kuat dimana korban tidak memiliki kekuatan untuk melawan. Sedangkan menurut (Rigby, 2019), mengidentifikasi konsep bullying sebagai perilaku penindasan yang umum ditemukan terjadi melalui tindakan fisik, menyakiti, marah, penindasan dunia maya, perilaku seksual dan ras bisa terjadi dimana saja seperti di kelas, halaman kelas, saat perjalan pulang. Dari beberapa konsep intimidasi di atas dapat disimpulkan bahwa intimidasi atau perundungan dapat terjadi berulang-ulang, merupakan golongan perilaku agresif, penindasan yang terjadi melalui dunia maya, dan adanya hubungan kekuasaan atau pelaku memiliki kekuatan tanpa perlawan dari korban. 
Perspektif Orang Tua Tentang Perilaku Bullying Anak TK: ditinjau dari Tingkat Pendidikan

DOI: $10.31004 /$ obsesi.v5i2.939

\section{Bahaya Perilaku Bullying Bagi Anak TK}

Perilaku bullying bagi anak TK yang tidak mendapatkan intervensi awal atau dibiarkan terjadi oleh guru dan orang tua sering menjadi faktor pemicu awal timbulnya perilaku tersebut secara berulang dan memiliki dampak yang negatif. Hasil wawancara dari perspektif orang tua tentang bahaya perilaku bullying bagi anak TK dengan indikator bagaimana orang tua mengenal bahaya perilaku bullying anak?. Jawaban orang tua dirangkum pada tabel 2.

Tabel 2. Perspektif orang tua tentang bahaya perilaku bullying bagi anak TK

\begin{tabular}{ll}
\hline \multicolumn{1}{c}{ Lulusan } & \multicolumn{1}{c}{ Perspektif Orang Tua } \\
\hline \multirow{3}{*}{ Sekolah } & Perspektif 2 orang tua dengan tingkat pendidikan terakhir SD yaitu, PMK dan \\
Dasar (SD) & VT mengatakan bahwa pernah anak kami melakukan tindakan fisik atau \\
& perkalian di taman kanak-kanak dalam bermain disebabkan oleh berebutan \\
& mainan. Namun perbuatan tersebut tidak terjadi secara berulang dan kami \\
& menegur anak kami tetapi apakah termasuk dalam perundungan atau bahaya \\
& dari bullying. Kami sendiri masi belum cukup paham sehingga kami mencobah \\
& untuk bertanya kepada guru wali kelas dan orang tua lain mengatakan kepada \\
& kami bahwa bullying membuat anak takut kesekolah.
\end{tabular}

Sekolah

Menengah

Pertama (SMP)

Sekolah

Menengah Atas

(SMA)

Sarjana
Hasil wawancara Perspektif orang tua dengan tingkat pendidikan akhir SMP 2 orang, YGO dan YWL mengatakan kami tahu bahaya bullying tidak baik untuk anak kami, apa lagi terjadi di sekolah. Harapanya anak kami di TK tidak mengalami bully. Kami juga sering mendengar kata bullying dari orang tua teman anak kami. Bahwa membully membuat anak kurang semangat atau sering murung dan sedih. Tapi sampai sejauh ini anak kami belum mengalami bully.

Hasil wawancara orang tua dengan tingkat pendidikan terakhir SMA, MNW mengatakan bahwa anak mereka belum pernah terlibat dan mengalami perilaku bullying di taman kanak-kanak. Namun saya tahu bahwa bullying sering membuat anak sedih dan terkait bahaya perilaku tersebut dapat berbahaya secara fisik dan psikis. Harapanya semoga anak saya tidak terlibat membully teman di sekolah maupun menjadi korban bully oleh temannya.

Hasil wawancara orang tua dengan pendidikan terakhir sarjana 1 orang, DS terkait bahaya perilaku bullying bagi anak TK mengatakan saya, memahami bahaya bullying bagi anak usia TK karena dapat berdampak pada faktor psikologi dan fisik anak seperti murung dan sedih juga membuat anak tidak kesekolah karena takut dengan teman yang membully. Perilaku perundungan ini harapanya tidak terjadi pada anak tk atau anak usia prasekolah.

Berdasarkan hasil wawancara pada tabel 2, penulis dapat meyimpulkan bahwa orang tua sudah memiliki pemahaman terhadap bahaya perilaku bullying dari perspektif mereka bahwa bahaya bullying dapat membuat anak murung, sedih, terganggung secara psikologi dan fisik namun pandangan orang tua masih perlu mencari informasi atau akses untuk mengenal bahaya bullying lebih mendalam dan memahami bahaya apa saja yang akan terjadi pada anak. Adapun dampak dari perilaku bullying di taman kanak-kanak berpengaruh pada psikologis seperti kecemasan, maupun trauma, adanya penolakan teman sebaya, tidak merasa nyaman di sekolah, peningkatan ketakutan, harga diri rendah dan dampaknya bagi fisik anak (luka memar, trauma fisik) (Swearer et al, 2010). Hal ini juga, tidak menutup kemungkinan bagi anak yang lain dalam menyaksikan terjadinya perilaku bullying di taman kanak-kanak dapat mempersepsikan bahwa perilaku tersebut boleh dilakukan (Muthmainna et al., 2014). 
Bahaya perilaku bullying lain yang lebih spesifik untuk memberikan pemahaman mendalam bagi orang tua adalah dibedakan dari anak sebagai pelaku dan korban bullying dimana pelaku bullying memiliki kriteria sebagai orang yang kuat menekan dan mengendalikan untuk mendapatkan kebutuhan mereka atau teman sebaya yang lebih tua, mudah marah dan tidak sabar, menjadi lebih agresif, pemberontak untuk orang lain termasuk kepada orang tua dan guru, memiliki rasa simpati kurang, dan mengintimidasi orang lain serta lebih cendrung bergaul dengan orang dewasa. Adapun bahayanya bagi anak yang menjadi korban bullying dimana menampilkan sikap rendahnya harga diri, menarik diri, pemalu, menjadi gelisah, sedih karena trauma secara psikologi, susah tidur, trauma fisik, mimpi buruk, dan menghindari ke sekolah (Saracho, 2017). Pendapat yang sejalan dikemukakan oleh (Stephens et al., 2018) dengan membagi bahaya atau efek dari perilaku bullying pada anak yaitu efek jangka pendek (gangguan kepribadian, melakukan masalah, menghindar dari sekolah, dan depresi), sedangkan efek yang kedua dalam jangka waktu yang lama dapat menimbulkan (anti sosial, agresi, bagi remaja dapat mengarah pada penggunaan obat terlarang maupun miras).

Dari berbagi bahaya atau dampak yang ditimbulkan dari perilaku bullying anak-anak menampilkan bahwa resiko besar terhadap perilaku tersebut akan sangat berefek pada perkembangan anak dalam rentang usia perasekolah. Bayangkan jika, seorang anak dengan usia dini melakukan tindakan bullying dan tidak mendapat intervensi dari orang tua atau diabaikan tentunya perilaku tersebut akan berkembang dan terjadi berulang-ulang. Penelitian (Kirves \& Sajaniemi, 2012), menemukan usia 5-7 tahun anak yang merupakan korban bullying cendurung mengalami kesalahan ketika beradaptasi selama tahun-tahun awal sekolah mereka. Pendapat di atas menekankan bahwa anak dengan rentang usia tersebut yang merupakan korban bullying masi mengalami gangguan psikologi sehingga perlu penyesuaian diri secara perlahan-lahan. Selain itu, tingkat pendidikan orang tua dan perspektif mereka terkait perilaku bullying sangat berperan membantu pencegahan dari bahaya perilaku tersebut bagi anak.

\section{Keterlibatan Orang Tua dalam Mengintervensi Awal Perilaku Bullying Anak}

Orang tua yang terlibat dalam memberikan pencegahan awal perilaku bullying anak di taman kanak-kanak memainkan peran penting dalam mendukung perkembangan pribadi anak. Hasil wawancara tentang keterlibatan orang tua dalam mengintervensi perilaku bullying anak dengan indikator. Hal-hal apa saja yang telah anda lakukan sebagai orang tua dalam menangani perilaku bullying anak? atau tindakan pencegahan apa saja yang sudah dilakukan terhadap perilaku intimidasi anak ditaman kanak-kanak?. Melalui indikator tersebut diperoleh hasil wawancara perspektif orang tua pada tabel 3.

Dari hasil wawancara tentang perpektif orang tua di atas terkait dengan Langkahlangkah intervensi atau pencegahan perilaku bullying menggambarkan bahwa orang tua dengan pendidikan terakhir sekolah dasar masih memahami bahwa pemberian hukuman menjadi solusi, sedangkan orang tua dengan tingkat pendidikan SMP dan SMA sudah lebih memahami bahwa pencegahan dapat dilakukan dengan mengajak anak untuk berkomunikasi atau berbicara sebagai pendekatan yang dapat membantu psikologi anak. Orang tua dengan pendidikan sarjana memiliki pemahaman mendalam bagaimana mencegah perilaku bullying dengan memberikan ruang bagi anak untuk berbagi, mengajarkan hal positif dan peka terhadap perubahan perilaku anak serta membangun solusi dengan pihak sekolah.

Selain itu, orang tua dapat dikatakan sebagai model yang memiliki kelekatan utama dengan diri anak secara emosional sehingga dapat mengembangkan perilaku yang mendukung pengendalian diri anak terhadap perilaku bullying yang terjadi ditaman kanakkanak atau tidak menjadi korban maupun pelaku bullying (Dey Putri et al., 2020). Beberapa bentuk penangan bullying yang ditawarkan bagi orang tua agar dapat mengintervensi lebih awal perilaku anak mereka dijabarkan oleh peneliti pada tabel di 4 . 
Perspektif Orang Tua Tentang Perilaku Bullying Anak TK: ditinjau dari Tingkat Pendidikan

DOI: 10.31004/obsesi.v5i2.939

Tabel 3. Perspektif orang tua dalam mengintervensi atau tindakan pencegahan perilaku bullying anak

\begin{tabular}{|l|l|}
\hline Lulusan & \multicolumn{1}{c|}{ Perspektif Orang Tua } \\
\hline Sekolah & $\begin{array}{l}\text { Hasil wawancara dari 2 orang tua, PMK dan VT dengan tingkat pendidikan } \\
\text { terakhir SD mengatakan bahwa jika anak kami terlibat maupun menjadi korban } \\
\text { bullying maka tindakan pencegahan yang kami tempuh dapat dengan langsung } \\
\text { memberikan hukuman dengan mencubit, menegur anak, dan kami juga } \\
\text { melaporkan ke pihak sekolah atau wali kelas. Kami percaya pihak sekolah bisa } \\
\text { membantu dan melihat anak-anak di sekolah. }\end{array}$ \\
\hline $\begin{array}{l}\text { Sekolah } \\
\text { Penengah } \\
\text { (SMP) }\end{array}$ & $\begin{array}{l}\text { Hasil wawancara orang tua dengan tingkat pendidikan terakhir SMP 2 orang, } \\
\text { YGO dan YWL memiliki konsep intervensi atau pencegahan perilaku bullying } \\
\text { berbicara, dan menanyakan anak kami terlebih dahulu apakah mengalami } \\
\text { bullying saat di sekolah misalnya (mendapat gangguan, kekerasan fisik) serta } \\
\text { perilaku tersebut apakah terjadi berulang-ulang. Melaporkan pihak sekolah atau } \\
\text { guru wali cara yang menurut kami bisa ditempuh untuk mengatasi perilaku ini. }\end{array}$ \\
\hline $\begin{array}{l}\text { Sekolah } \\
\text { Menengah } \\
\text { (SMA) }\end{array}$ & $\begin{array}{l}\text { Hasil wancara orang tua dengan tingkat pendidikan terakhir SMA 1 orang, } \\
\text { MNW mengatakan saya akan mengajak anak saya berbicara dengan terbuka } \\
\text { menceritakan masalah atau persoalannya. Saya akan melaporkan keguru wali } \\
\text { kelas terkait dengan anak saya, apabilah anak saya sendiri yang mungkin } \\
\text { melakukan hal bully tersebut maka intervensi atau pencegahan dapat } \\
\text { berkomunikasi dengan pihak guru atau kepala sekolah. }\end{array}$ \\
\hline Sarjana & $\begin{array}{l}\text { Hasil wawancara perspektif orang tua dengan tingkat pendidikan terakhir } \\
\text { sarjana guru 1 orang yaitu Ds mengatakan terkait tindakan yang dilakukan } \\
\text { untuk mencega bullying. saya terlebih dahulu akan mengajarkan berbagai hal } \\
\text { positif termasuk sikap asertif pada anak saya, membangun komunikasi dengan } \\
\text { anak, peka terhadap perubahan perilaku anak, dan membangun komunikasi } \\
\text { dengan sekolah jika anak saya mungkin menjadi korban maupun sebagai pelaku } \\
\text { intimidasi saya berharap adanya kerjasama pihak sekolah dan orang tua untuk } \\
\text { dicarikan solusi. Saya juga, bertanya kepada anak saya saat di sekolah begaimana } \\
\text { dengan teman-teman saat bermain dan belajar apakah semuanya baik, atau } \\
\text { adakah yang nakal dan suka menggangu. Hal demikian merupakan cara saya } \\
\text { agar mencega adanya perilaku bullying bagi anak saya. }\end{array}$ \\
\hline
\end{tabular}

Berbagai aspek-aspek yang dijabarkan di atas mengedepankan sikap peka orang tua dalam keterlibatan mereka untuk memberikan intervensi maupun perhatian melalui dukungan emosional bagi anak serta mendidik, dan mengajarkan berbagai hal positif tentang tindakan pencegahan yang diambil oleh anak dalam mengatasi perilaku bullying. Selain itu, (Ttofi \& Farrington, 2011) mengatakan bahwa orang tua penting untuk terlibat dirumah dan sekolah. Agar memperoleh berbagai informasi tentang perilaku bullying dan membangun komunikasi dengan sekolah baik terlibat dalam pelatihan maupun sharing bersama tentang konsep intimidasi sehingga dapat mengambil langkah bersama untuk mencega dan mengatasi. Harapannya sekolah juga memfasilitasi hubungan orang tua dan sekolah melalui konsultasi terkait respon kolektif orang tua terhadap perilaku bullying di taman kanak-kanak agar membangun perspektif yang luas terhadap pemahaman bullying bagi orang tua 
Tabel 4. Aspek Penanganan Perilaku Bullying

\begin{tabular}{ll}
\hline \multicolumn{1}{c}{ Penanganan } & \multicolumn{1}{c}{ Keterangan } \\
\hline Membangun & Komunikasi orang tua dan anak adalah faktor pendukung terbangunnya hubungan \\
Komunikasi & emosional yang positif. Anak dapat dengan terbuka mengungkapkan apa yang dirasakan \\
Dua Arah & bahkan perilaku bullying sekalipun bila terjadi pada dirinya akan disampikan kepada \\
Antar Orang & orang tua apabila orang tua terbiasa memberikan ruang itu bagi anak mereka. Namun \\
Tua -Anak & pemahaman terhadap komunikasih yang baik masih menjadi permasalahan dikalangan \\
& $\begin{array}{l}\text { orang tua sendiri. Selain itu, didukung oleh pandangan Muthmainna et al, (2014) } \\
\text { mengatakan orang tua juga perlu terlibat menjadi pendengar yang baik untuk anak } \\
\text { dengan membiarkan anak mengutarakan pendapat sebagai bentuk upaya anak untuk } \\
\text { belajar mengenal diri, mengendalikan emosional, dan mampu mengelola perilaku. }\end{array}$
\end{tabular}

Sikap dan Pemahaman

Orang Tua

Terhadap

Perilaku

Bullying

Menajeman

Keluarga

Gaya

Pengasuhan

Orang Tua

Bermain Peran

Bersama Anak

Pengawasan

Kualitas,

Kehangatan,

dan Perhatian

Bekerjasama

Dengan Pihak

Sekolah
Orang tua sangat dekat dengan anak mereka di rumah bahkan mengenal perilaku anak mereka. Pengambilan sikap terhadap perilaku bullying adalah peran orang tua dalam memberikan pengetahuan kepada anak dengan memberikan informasi yang cukup jelas serta menyampaikan cara-cara dalam mensikapi tindakan bullying apabila terjadi.

Melalui menajemen keluarga orang tua dapat membangun suatu kesepakatan dengan anak terkait pengajaran tentang perilaku disiplin, sosial, interaksi yang terjadi dalam lingkungan keluarga dan anak juga patut untuk mengikuti aturan-aturan yang telah disepakti bersama serta membatasi diri terhadap perilaku yang merugikan atau tidak mendidik seperti ungkapan kata kasar, perilaku bullying, melawan, dan tidak patuh. Cross and Barnes (2014) mengatakan bahwa keterlibatan orang tua dalam membangun sistem atau menajemen dalam keluarga dapat memberikan penguatan terhadap perilaku disiplin dan interaksi sosial anak yang positif dalam menekan bullying terjadi.

Pola asuh orang tua sangat mendukung perkembangan emosional dan membangun perilaku anak secara matang. Pemilihan pola asuh yang tepat membantu anak tumbuh dan berkembang dengan baik dalam lingkungan keluarga dan lingkungan sosial secara luas. Anak yang mendapatkan pola asuh yang tepat dari orang tua akan berkembang secara sikap atau karakter lebih maju dan dapat mengatasi bullying lebih baik. Jannah, (2017) mengatakan pemilihan pola asuh oleh orang tua seperti, pola asuh demokratis menumbuhkan perilaku dalam diri anak lebih percaya diri, dapat bersikap sopan, mengendalikan diri, dan mampu membangun hubungan kerjasama dengan orang lain.

Usia anak yang ada pada tahap bermain menjadi kunci utama bagi orang tua untuk mengajarkan berbagi perilaku-perilaku baik kedalam diri anak. bermain peran dapat membantu anak berkembang secara emosional dan menjadi kesempatan untuk memperkenal cara mengatasi bullying. Muthmainna et al, (2014) mengatakan Orang tua dapat memili tema yang baik untuk memberikan contoh perilaku-perilaku seperti mengganggu dan menyakiti orang lain perlu untuk dihindari dan tidak dilakukan oleh anak dan apabila anak menemukan hal tersebut ditaman kanak-kanak maka anak dapat dengan terbuka berkomunikasi dengan guru maupun orang tua.

Orang tua dapat membangun pengawasan secara kualitas tentang perkembangan perilaku anak mereka dengan memberikan kehangatan dan perhatian. Pengawasan kualitas yang dimaksudkan mengontrol dan mengintervensi lebih dini apa bilah ada perilaku yang menyimpang dari anak semisalnya perilaku bullying atau perilaku agresif. Cross and Barnes (2014) menekankan bahwa orang tua yang memberikan pengawasan kualitas terhadap perilaku anak dapat menumbuhkan pencegahan lebih awal terhadap perilaku agresif anak maupun intimidasi.

Apabila merujuk pada hasil wawancara orang tua, hampir semua orang tua mengatakan bahwa pencegahan perilaku bullying dengan melaporkan hal tersebut kepada pihak sekolah dan ini merupakan salah satu solusi yang menurut peniliti harus dipilih dengan alasan, bahwa anak berkembang secara emosional karena campur tangan sekolah dan pihak sekolah akan dengan terbuka membantu untuk mengatasi berkembangannya perilaku bullying dan mencarikan solusi yang terbaik. Selain itu, menurut Swearer et al, (2010) intervensi bullying tidak terlepas dari tingkat inisiatif keluarga, sekolah, individu, dan komunitas. 


\section{Tingkat Pendidikan Orang Tua}

Orang tua dengan tingkat pendidikan terakhir yang berbeda atau pernah bersekolah sampai pada tingkat pendidikan yang lebih tinggi tentu memiliki gambaran secara umum bahwa pernah mendengar tentang bullying atau bahkan memiliki perspektif pemahaman konsep bullying dengan baik. Pemahaman itu tidak terlepas dari tingkat pendidikan dan kemudahan orang tua dalam memiliki akses informasi yang luas untuk mencari tauh tentang bullying baik melalui teknologi penyedia informasi, sharing bersama guru, atau bahkan pernah menyaksikan perilaku tersebut terjadi dilingkungan sosial anak-anak mereka. Apabila orang tua berpendidikan tinggi sudah tentunya memiliki akses lebih luas untuk mempelajari atau mencari tahu tentang perilaku bullying anak dan efeknya untuk perkembangan anak. Karena orang tua sendiri dikatakan sebagai peletak dasar segalah pengetahuan atau modelling bagi anak dalam mengatasi perilaku bullying (Dey Putri et al., 2020).

Semakin tinggi pendidikan orang tua tentunya mereka akan memiliki pandangan yang luas juga kritis untuk mengambil bagian dan terlibat dalam menangani perilaku bullying yang terjadi pada anak-anak mereka ditaman kanak-kanak. Dimana orang tua merupakan sumber informasi utama bagi anak dalam keluarga dan mengenal tentang ajaran sosial dan emosional sebagai dasar penguatan pribadi anak untuk menghindari perilaku bullying (Papanikolaou, et al. 2011).

Pemahaman konsep bullying adalah hal yang paling utama untuk memberikan wawasan awal bagi orang tua bahwa perilaku tersebut memiliki efek yang sangat negatif bagi perkembangan anak. perilaku tersebut tidak diterima secara sosial disebabkan oleh dampaknya yang lama berpengaruh negatif pada diri anak atau anak mengalami trauma dan bahkan dapat terjadi depresi yang mengakibatkan anak akan berpeluang untuk bertindak negatif. Oleh karena itu, pendidikan orang dan keterlibatan orang tua yang semakin tinggi akan lebih baik dalam mengenal konsep bullying dan mengambil Tindakan pencegahan yang tepat.(Cross \& Barnes, 2014).

\section{SIMPULAN}

Berdasarkan hasil penelitian yang dilakukan, penulis menemukan bahwa orang tua anak memiliki perspektif tentang perilaku bullying anak TK, yang dimaknai dari beragam pemahaman yang berbeda dengan latar tingkat pendidikan akhir orang tua. Dimana pendidikan orang tua berkaitan dengan perspektif mereka yang mendalam dan luas tentang perilaku bullying anak sampai pada pengambilan intervensi atau pencegahan.

\section{UCAPAN TERIMAKSIH}

Terima kasih kepada berbagai pihak yang telah membantu penulis. Khususnya orang tua dari anak, dan pihak sekolah TK Tunas Harapan Weetebula sehingga penelitian ini dapat selesai dan berjalan dengan lancar.

\section{DAFTAR PUSTAKA}

Akerman, L., Borsa, J. C., Landim, I., \& Bienemann, B. (2018). Brazilian caregivers' conception on child bullying. Psicologia: Reflexao e Critica, 31(1). https://doi.org/10.1186/s41155018-0113-0

Christensen, L. B., Johnson, R. B., \& Turner, L. A. (2015). Research Methods, Design, and Analysis twelfth edition.

Cross, D., \& Barnes, A. (2014). Using Systems Theory to Understand and Respond to Family Influences on Children's Bullying Behavior: Friendly Schools Friendly Families Program. Theory into Practice, 53(4), 293-299. https://doi.org/10.1080/00405841.2014.947223

Dey Putri, L. A., Yetti, E., \& Hartati, S. (2020). Pengaruh Keterlibatan Orangtua dan Regulasi Diri terhadap Perilaku Bullying Anak Usia Dini. Jurnal Obsesi : Jurnal Pendidikan Anak Usia Dini, 4(2), 715. https://doi.org/10.31004/obsesi.v4i2.438 
Ditha Prasanti, \& Dinda Rakhma Fitriani. (2018). Pembentukan Karakter Anak Usia Dini: Keluarga, Sekolah, Dan Komunitas. Program Studi Ilmu Komunikasi Fakultas Ilmu Komunikasi Universitas PadjadjaranProgram Studi Ilmu Komunikasi Fakultas Ilmu Komunikasi Universitas Gunadharma, 2(1), 13-19.

Elmahera, D. (2018). Analisis Bullying Pada Anak Usia Dini. Prosiding Seminar dan Diskusi Nasional Pendidikan Dasar.

Harcourt, S., Jasperse, M., \& Green, V. A. (2014). "We were Sad and We were Angry": A Systematic Review of Parents' Perspectives on Bullying. Child and Youth Care Forum, 43(3), 373-391. https:// doi.org/10.1007/s10566-014-9243-4

Hein, N. (2017). New perspectives on the positioning of parents in children's bullying at school. British Journal of Sociology of Education, 38(8), 1125-1138. https:/ / doi.org/10.1080/01425692.2016.1251305

Herne, K. E. (2016). 'It's the parents': re-presenting parents in school bullying research. Critical Studies in Education, 57(2), 254-270. https:/ / doi.org/10.1080/17508487.2014.988635

Jannah, M. M. (2017). Dentifikasi Pola Asuh Orang Tua Di Taman Kanak-Kanak Aba Jogokaryan Yogyakarta. Jurnal Pendidikan Anak Usia Dini Edisi 6, 1-8.

Kirves, L., \& Sajaniemi, N. (2012). Bullying in early educational settings. Early Child Development and Care, 182(3-4), 383-400. https:/ / doi.org/10.1080/03004430.2011.646724

Maria, I., \& Novianti, R. (2017). Pengaruh Pola Asuh dan Bullying Terhadap Harga Diri Pada Anak Kelompok B TK di Kota Pekanbaru. Jurnal Prodi Keguruan Universitas Riau, 6(1), 61-69.

Papanikolaou, M., Chatzikosma, T., \& Kleio, K. (2011). Bullying at school: The role of family. Procedia - Social and Behavioral Sciences, 29, 433-442. https:// doi.org/10.1016/j.sbspro.2011.11.260

Rigby, K. (2019). How Australian parents of bullied and non-bullied children see their school responding to bullying. Educational Review, 71(3), 318-333. https:/ / doi.org/10.1080/00131911.2017.1410104

Robbiyah, R., Ekasari, D., Witarsa, R., \& Robbiyah, E. dan W. (2018). Pengaruh Pola Asuh Ibu terhadap Kecerdasan Sosial Anak Usia Dini di TK Kenanga Kabupaten Bandung Barat. Jurnal Obsesi, 2(1), 76-84. https://doi.org/10.31004/obsesi.v2i1.10

Santoso, A. (2018). Pendidikan Anti Bullying. Pelita Ilmu, 1(2), 49-57.

Saracho, O. N. (2017). Bullying Prevention Strategies in Early Childhood Education. Early Childhood Education Journal, 45(4), 453-460. https:/ / doi.org/10.1007/s10643-016-0793$\mathrm{y}$

SHARP, S., \& SMITH, P. K. (2019). Understanding Bullying. Tackling Bullying in Your School, 1-6. https://doi.org/10.4324/9780203425503-1

Stephens, M. M., Cook-Fasano, H. T., \& Sibbaluca, K. (2018). Childhood Bullying: Implications for Physicians. American family physician, 97(3), 187-192.

Swearer, S. M., Espelage, D. L., Vaillancourt, T., \& Hymel, S. (2010). What can be done about school bullying? linking research to educational practice. Educational Researcher, 39(1), 38-47. https:/ / doi.org/10.3102/0013189X09357622

Ttofi, M. M., \& Farrington, D. P. (2011). Effectiveness of school-based programs to reduce bullying: A systematic and meta-analytic review. Journal of Experimental Criminology, 7(1), 27-56. https:/ / doi.org/10.1007/s11292-010-9109-1 